\title{
The Rushdie Confrontation: A Clash in Values
}

\section{T. B. Irving}

In October 1988, when Impact International of London first published its alert on Salman Rushdie's The Satanic Verses, I dismissed the issue as scarcely worth considering. Sensational novels of this sort, and films as well, generally do not repay the time spent on them, unless some larger concern may make this effort imperative.

That moment has arrived and in fact is past due, as the Rushdie affair has gained the attention of the vast Islamic world that stretches from North and West Africa on the Atlantic eastward to Indonesia on the Pacific and has created a confrontation with the West where His Eminence the Ayatollah Khomeini once more played a key figure on the world stage.

The five persons who lost their lives in Islamabad, Pakistan, on February 12th, 1989, induced His Eminence to study the matter and render a decision. Then more deaths occurred in India. The Ayatollah's death sentence and the price placed on Salman Rushdie's head remind one of the bounty offered for bank and train robbers in the American Wild West during the past century. Even in this century, such posters could be seen in post offices and public buildings offering a monetary reward if the wanted man was caught. Jesse James was sought "dead or alive" in exactly the same way. Perhaps that makes the sheriff who published such a notice a "murderer" as Khomeini has been called.

This novel should not be censored but ignored. The Satanic Verses offers the West a confused and false picture of Islam, as has been the image of the religion in Europe ever since the Crusades and the Castilian and Aragonese "reconquest" of Andalusia and Granada from where this prejudice has now come to America. Neither side understands the other fully, nor attempts to do so; yet at this moment neither wants to surrender to rationality. Mozart's Abduction from the Seraglio formed part of this folklore two centuries ago with its prurient interest in Ottoman harems and Eastern mysteries (which again recalls the same interest in the Orient that one reads in The Golden Ass of the Algerian - and not Moroccan, as Rushdie states on page 243-writer Apuleius). The city of Matamoros across the river in Mexico from Brownsville, Texas, literally means "Moor-slayer," and shows how ingrained this putting down of the Moor and Muslim has 
been. The Spanish Inquisition still remains as a deep wound whose affront to human rights is shrugged off by the same figures who shout loudly for freedom of expression today.

The Satanic Verses is a dirty book and worse; it mocks sacred matters deliberately. The novel, plainly put, is vulgar and offers offense to most Muslims. The author probably calculated this effect in order to give his work publicity, but he misjudged the sudden force of its rejection by the Islamic world. Rushdie's earlier novel, Midnight's Children, was banned in India in 1981 for offending the Gandhi family in the same vulgar fashion. Shame (1983) achieved the same publicity and censure in Pakistan by exploiting the Bhutto-Zia duel to the death, it might be said. Even the present novel mentions Indira and her "son, the airline pilot" (25) contemptuously. In similar fashion the prime minister of Britain becomes "Mrs Torture" in The Satanic Verses. Yet financial assistance to write Shame came from the Arts Council of Great Britain!

Salman Rushdie expected the opposition to his book would be heard and then die down, as it did with the film The Last Temptation of Christ last year or The Message on the life of the Prophet during the 1970s. Since this affair is now public, the author should be called to account because his message will not lead to any better understanding on the part of the West concerning Islam and the world Muslim commumity. Non-Muslim reviewers of The Satanic Verses do not seem to understand Islamic considerations nor even how to pronounce Islamic names in either the Arabic or Indo-Muslim traditions, while their indignation and smugness at the denial of "free expression" to Mr. Rushdie is as high and holy as the sanctimony that these critics attribute to fundamentalist Muslims. Salman Rushdie is a good writer perhaps, but a smutty one in the Anglo-Indian or "Chichi" manner. Few Britishers would recognize "Mahavilayet" as his disguise for Great Britain. Who in the West would relate "Isa born to Maryam" (118) as Jesus? Like tea and teak, this is an Indian gift to the English-speaking world; the Hindu trappings of Rushdie's half-learned Islam underscore his loss of faith, and make his insolence understandable. Senator John Tower's lame promise to stop drinking if he were confirmed as Secretary of Defense matches Rushdie's despicable half-apology for writing The Satanic Verses.

Conversely Muslim reviewers are not accustomed to making literary judgments because they commonly do not read novels, let alone surrealistic ones. The modern novel of character is not Islamic, Arab, or Indian; al- 
though The 1001 Nights and the novel of episodes that grew out of it have supplied us with many of the stock figures in our folklore: Sinbad the Sailor, Ali Baba and his Forty Thieves, Aladdin and his Magic Lamp, to leave them in their usual English form. The fiend "Mahound" is one of these characters, a medieval bogey coined during the Crusades as a vulgar parody of the Prophet. The novel of character that began with Don Quijote over four hundred years ago gives us the model for the two protagonists here in Gibreel Farishta and Saladin Chamcha, who interreact as a symbolic angel and devil, forming a tour de force that sustains the narrative. The jumbo jet blows up surrealistically on p. 2 of the novel in imitation of the Air India plane that disappeared off the Irish coast in 1985; the only survivors are our protagonists, Gibreel and Saladin, we are asked to believe. The narrative then moves along on a system of flashbacks on several levels in cinematographic fashion (the mention of Lockerbie, Scotland, on page 431 is prescient to this mood).

Gibreel and Saladin are Bombay Muslims, "us wogs" as Rushdie calls them (51). They jumble things up with "other treasons" (49). Gibreel has been a movie star in India, playing Hindu gods in the Bombay cinema. He is forty years old when our story opens, and worried about his fading career. D. W. Rama, the great movie magnate, has combed the Hindu pantheon and Sanskrit epics for scripts for him. Gibreel spent four years on the movie lot in the beginning, as a stooge. In the hospital, a national crisis develops at the star's illness (28), with Rajiv Gandhi in attendance!

Saladin Chamcha is our second figure with the Bombay lilt, who displays "masks beneath masks" (25). His father, Changaz Chamchawalla (cf. Genghiz Khan), makes chemical fertilizers and is wealthy. Salahaddin, to give him his classic first name, begins as a thirteen-year-old boy who wants to leave home, to escape in a teenage revolt, as in the episode of the lost wallet which his father seizes from him. The rich boy migrates to England, where he lives under little supervision. Saladin's first fortnight in London eating kipper and having other experiences, anticipates his future. He finds work as an actor and finally as a dubber on commercials: his thousand voices "ruled the airwaves" (60). Later his telephone voices plague his friends. A thoroughly secular man results (43); surrealistic motifs abound as when he survives the explosion of the aircraft and emerges with horns and hoofs.

Meanwhile his mother has died: "You should not blaspheme," her 
ghost tells him (66), and especially on p. 102, where blasphemy is said to be "punished by death," which ironically justifies Khomeini's sentence. The profession of faith recited with the medieval name of "Mahound" rather than Muhammad's inserted into it is a twist that becomes clearly blasphemous on p. 374. Here Rushdie admits he has written blasphemy, and worse than that, in wretched taste. Is there a God? he asks. Is there a devil? The non-existence of "Gods" is suggested. Eating "unclean pigs" in the Taj hotel forms an obsession (83), as it is for slack Muslims and for some Jews in our society. Saladin calls beer a "refreshing drink."

How many Western critics or ordinary readers for that matter, catch these points? "Where there is no belief, there is no blasphemy," pleads the writer in shocked innocence (380). The crime or sin of blasphemy implies grossly outrageous language concerning God or some inviolable object, showing contempt or offering indignity for the Deity by word or in writing. In Islamic law, this applies to the Qur'anic text and to the names of God and the Prophet. In most countries, this offense was punished severely, generally by death, till this present century.

Chapter II is patently disgusting for a real Muslim, as is Chapter VI. Both will only serve to confuse the Western reader about Islam, or rather Rushdie's idea of it. Here the story of "Mahound" is a crude caricature of the Sira or classic biography of the Prophet.

The second chapter repeats old legends (asātir al-awwalin as the Qur'an calls them) that are quite well-known to scholars. Mr. Rushdie has taken on too much in his irreverence and disrespect, especially with his journalistic and Bombay jargon which he uses to describe Islam. The grandiose figure of $A l l a h$ or God Alone is contrasted with the three pagan goddesses of ancient Mecca: Al-Lat (the feminine of Allah, which makes it polytheistic, and thus anathema), Manat, and Uzzà, who are mentioned in the Qur'an (53:20-21) and whose characters Rushdie has taken from Thabari or similar apocryphal sources. Allie Cone, Chamcha's Jewish girlfriend who climbed Mt. Everest, the "exalted bird" as he calls her, is compared to Al-Lat, the pagan mistress of pre-Islamic Mecca. Tabari was a Persian historian and commentator who revised the prophetic traditions of his day; these unconfirmed legends offered images which were discussed by the Mu'tazilites in Baghdad during the IXth and Xth centuries, and the Ikhwan as-Safa or "Brethren of Purity," the encyclopedists of that period. 
All this is apocryphal gossip and should be presented to the public, if at all, as the nonsense that it was and is.

Salman the Persian wrestles with Gabriel, the archangel (as suggested in Chapter 53 in the Qur'an, called The Star) as if we were watching a Bombay movie plot: "Gibreel saw God," to reinforce his archangelic status "standing . . . upon the western horizon" (The Star 53:6 \& 336 in the novel). "His arms to fill the sky" is an ugly and daring figure for Muslims but mixed up with four-letter words like "yoni" drawn from the Kamasutra.

The mocking derivation of Muhammad's name and of Jahilia (Jahiliyya or "ignorance") for Mecca, the still sacred city of Islam, is scandalous. Rushdie likewise mocks the patriarch Abraham or Ibrahım in Arabic, the common ancestor of the Arabs and Hebrews. Was his elder son Ismail a "bastard" (95)? Rushdie here seems to prefer the Hebrew account of Genesis, whereby Ismail's birth is acknowledged in Genesis 16 and then dismissed when Isaac becomes Abraham's "only son" (Gen. 22:2). Clear Arab and Islamic tradition is thus ignored or mocked.

Chapter VI has the title "Return to Jahilia." What does Jahilia mean to a Western reader? Who will understand this image? Rushdie has failed to leave more than a confusing image of Islam with the average reader. AbuSimbel's wife Hind, who ate Muhammad's uncle Hamza's liver raw, is an anachronism (36). In the 7th century, she cooks "couscous" in Mecca, French spelling and all.

Mahound, Rushdie's prophet, is obsessed by his concept of the Law. The names of the "Recitation" (354) and the "Rule Book" (385) make contemptuous fun of the Qur'an (which literally means the "Reading"). How will Mahound behave when he wins? we are asked. The common people of Yathrib (the ancient name for Madina) are landless and therefore poor, and attracted to the new faith for this reason, rather than by conviction or piety. They perform acts of brigandage, attacking camel trains or caravans.

The new prophet's poems are now full of loss as figures stalk away from him, mumbling the Creed. In Yathrib we meet Salman the Persian, who shares his name with Rushdie (365). Historically the Persian convert had a trench dug around the city that saved it during the siege of Uhud, which Rushdie calls "this foul piece" and "a cheap trick." The idea that destroyed Salman's faith was the fact that his guardian angel confirmed the changes 
he had made in the prophetic text which he was taking down in dictation, so that he invented passages on his own (385).

The temple of Uzzà, the "Mighty (Woman or Goddess)" by the city gates of Mecca, was cleansed by Khalid, the water carrier, who becomes chief-of-staff to Mahound. These points are much too close, yet derisively, to the official biography of the Prophet to be comical. The new prophet finally falls asleep, to avoid further trouble. In Jahilia no alcohol can now be found, while men go locking up their wives, and puritanism reigns. The newly puritanical streets shelter "skin-deep converts" who still want to eat pork (378). Baal the poet cringes in the brothel, disguised as a eunuch.

All of this is deliberately offensive, as if the Twelve Disciples were pictured as a homosexual gang indulging in gay parties in the Garden of Gethsemane or on a wild boat trip on the Sea of Galilee, simply because they have no women among them; while each disciple is assigned individual roles with caricatures of this offensive sort to carry the blasphemous narrative. Would such a story be considered hilarious freedom of expression by normal Christians? The brothel in Mecca makes a parody of $\mathrm{Mu}-$ hammad's home life and the Ka'ba, the center of Pilgrimage until today. His twelve wives (the number here is historically debatable) include a new Ayesha, a fifteen-year-old prostitute who takes the place of the child-bride whom the real Prophet favored, and mocks her, even to the tale of Ayesha returning from the camp escorted (controversially) by a young soldier. At the end, to Ayesha is attributed Abu-Bakr's famous statement following the Prophet's death that Muhammad was dead but that "God is Alive!" This is effrontery rather than poetic license, and for no apparent reason. The prophetic Sira or biography of the Prophet is deformed outrageously with these apocryphal tales. The whole book is a travesty, a parody on sacred values with all these slutty stories that Salman Rushdie has dredged up and delights in reading.

In the furor raised by his Life of Jesus in the 1860 s, over a hundred years ago, Ernest Renan lost his professorship at the Collège de France. That biography is now either accepted (grudgingly in some quarters) or has been forgotten. During the past century "higher criticism" of this sort scrutinized the sacred books of the East and West; Theodor Nöldeke and his German colleagues collected many of the stories we find in Chapter II and VI from pious folklore of many countries, presenting them to the religious literature of this century. 
However for the past forty years another type of censorship has increased on our information from the Middle East in journalistic and academic circles, and led to much frustration among those writers who are subject to it. In the matter of Palestine especially, only the Israeli point of view has been heard freely, to the point that officials in Washington, let alone New York and London, recite duck-billed platitudes about Israeli legitimacy while human rights do not exist in Palestine (as it did not in Inquisitorial Spain five centuries ago). So much is heard about the Holocaust of the Jews in Europe while we are witnessing daily how the Palestinians are being forced toward another annihilation. This, and the Algerian War for Independence where the French-controlled Western press called the Algerians "terrorists," and the Iranian revolt against the Shah, and similar incidents, have led to Muslim frustration with Western "due process" of law and information, an issue just as important as any freedom of expression. My own articles have been "edited" in this fashion and recast into Orientalist jargon with spellings like "Koran" and "Moslem" which are offensive to Muslims. Friday is said to be the "Moslem Sabbath" when yaw'm as-sabat clearly means "Saturday" in Arabic. Journalistic opinions on the subject of Islamic law or Shar'a are canned and kneejerk, whether this code applies to Pakistan, Nigeria, or other Islamic countries. Photographs of Muslims at prayer are taken at unfortunate, irreverent angles, showing disrespect for this rite, the Second Pillar of the faith.

Contemporary terrorism came first in Algeria during the 1950s and 1960s, until the French airforce killed Tunisian school children at Saqiat Sídi Yusuf; now Palestine holds the "terrorists" while Israeli politicians are received in the White House: Count Bernadotte in 1948 in Jerusalem, the King David Hotel, where the British governor and 80 other persons were blown to pieces, and Dayr Yasin on the road from Tel Aviv to Jerusalem have all been forgotten. The New Jersey shelled Druze and Shu'a villages in Lebanon, while the Christian and Maronite ones were left untouched; this shows the same prejudice as expressed by Alexander Haig when he served as Secretary of State and asserted his Georgetown-inspired directives on United States policy. Fortunately Haig did not remain long in office. However there still is a clear double standard for freedom and human rights towards Muslims that seems unfair, and has just burst into fury in this Satanic challenge.

The lack of schools and decent textbooks in the Middle East (and in 
Central America) has increased this sense of frustration, especially among the young. Those whom the West calls "terrorists" are schoolboys who have been deprived of proper teaching and textbooks, whether they are Algerian, Palestinian, or Iranian. This frustration concerns not only the youth, because at the age of seventy-five I have felt this pressure on my own freedom of expression through a half century of academic life in several universities.

The Spanish Inquisition and its abuse of human rights five centuries ago are seldom considered although these policies led to the holocaust of the Spanish Muslims. Journalism concedes little freedom of expression to the Muslim point of view, especially when a specialist is obliged to use journalistic jargon in order to express his views to the general public. The Associated Press in its New York and Cairo offices needs to review its rule book for its coverage on the Middle East, and base this on facts rather than Crusading and Zionist folklore about deserts being transformed into paradise on earth while the original inhabitants are called "terrorists," precisely like the long-suffering Algerians, but not the assassins of Count Bernadotte.

Mr. Rushdie shows some of this attitude in his use of the word "Submission" (and even "Submit" as a capitalized verb) for Mahound's new faith in Jahiliah. This is disconcerting because "Submission" repeats another Orientalist and especially French transformation of Islam: here "Submission" implies "polluting the Word of God with my own writing" as the Rushdian figure of Salman the Persian phrases it (367), which is highlighted by "your unbelief" (68), which makes Rushdie or Chamcha into a kafir or in Western parlance, an "atheist." Rushdie is not in touch with contemporary Islamic terminology and thought, but rather with antiquated Orientalist jargon that he half-learned at Cambridge and in the television and radio studios of London.

The book offers us some ideas and has some intellectual merit: the matter of Revelation is taken up, especially in the figure of Gabriel (to give the real angel its common English name). On the subject of Revelation and how the Qur'an was conceived, Muslims are quite clear. Khalid's deeper truth which he explores on p. 126, at the end of Chapter II is interesting. The nature of evil is another such theme (424), but that "God is the creator of evil" is aberrant; here Rushdie skates along the edge of a moral 
precipice, as he does with his Satanic thoughts and verses. As he defines them, these notions are not godly but Satanic. Evil, we are told, is never total (467), while God is its creator! Fortunately, Rushdie does not capitalize the word "creator."

Rushdie does not know Arabic, like many Indian Muslims who nonetheless may have memorized the text of the Qur'an. Nor does he understand its usage, as we observe with the repeated use of "qalmah" for kalimah (كلــ), the "word" for the Islamic Creed or profession of faith. Rushdie admits that he does not know Arabic (340). Abu-Simbel (Abu-Sufyan, the Prophet's bitter opponent in the Meccan establishment) and his wife Hind, in the end shriek the "qalmah" in desperation when the ruling family sees it has lost everything to Mahound (or Muhammad). However "Simbel" alone without the "Abu-" (383) is as if MacDonald should lose its patronymic prefix "Mac-."

The use of the word djinn for the "sprites" that are found in the Qur'an shows more French and Orientalist influence with its initial "d-." This word is a plural, not a singular, and requires no final "-s" to make the plural. Jinni is the singular, as with 'arab (plural) and 'arabi (singular). Similarly the nondescript diphthong "ou" borrowed from the French represents three distinct sounds as a short "u," a long " $u$," and the consonant "w"; these and other Orientalia are generally anti-Islamic and anti-Arab in their use.

We thus read a grotesque parody in The Satanic Verses where life is portrayed, but a sordid one; Islam is laughed at with its "antiquated" rules for human behavior, its sacred law, and its treatment of women. Nonetheless Islam is alive and growing today, even in North America, as the 200 writers who protested for their "freedom of expression" at the publishers on Fifth Avenue in New York last February found out. They were followed down that street by literally thousands of American Muslims (I have heard variously three, ten, twelve and even fifteen thousand as the number, and this by participants in the demonstratrion) who knelt and prayed on the same pavement. Have the New York City police noticed this, or did they choose to ignore it as they have done with the assassination of Malcolm X, a murder that has never been solved, and still rankles? This numerical contrast is important as a portent of the future: Muslims now represent one-fifth of the world's population in the broad band that 
runs from Morocco to Indonesia. Meanwhile North America still has to produce its own journal of Islamic opinion written in native English.

The Satanic Verses would best have been removed from the shelves; but since that is no longer possible and Salman Rushdie has taken upon himself to preach a flawed message, he lives with his misdeed till the Day for Repayment. 